\title{
Enteral nutrition as primary therapy in Crohn's disease
}

\author{
F Fernández-Bañares, E Cabré, F González-Huix, M A Gassull
}

\begin{abstract}
The developments in enteral feeding for Crohn's disease in the past decade are critically reviewed. The advent of amino acid based chemically defined elemental diets signalled the end of 'total bowel rest' in the management of these patients. Subsequently, controlled clinical trials showed that elemental diets were as effective as corticosteroids in inducing clinical remission in patients with acute exacerbations of Crohn's disease. The later use of peptide based elemental diets, in Crohn's disease produced somewhat conflicting results. The initial uncontrolled studies suggest that polymeric whole protein diets might also be effective in the management of acute exacerbations of the disease, casting in turn doubts concerning the role of dietary antigens in the pathogenesis of Crohn's disease. Results of controlled studies comparing the use of elemental and polymeric diets as primary therapy in Crohn's disease have, however, also produced conflicting results. The results of one recent controlled trial in which the use of polymeric diet was compared with that of corticosteroids does, however, suggest that these diets may have a primary therapeutic effect in Crohn's disease. An analysis of the composition of some of the enteral diets used in different trials suggest that the effectiveness of enteral diets in treating active Crohn's disease might relate more to their fat than nitrogen composition. A hypothesis is proposed that the effectiveness of enteral nutrition in the primary therapy of acute exacerbations of Crohn's disease occurs because the successful diets used contain insufficient precursors for arachidonate derived eicosanoid synthesis.

(Gut 1994; supplement 1: S55-S59)
\end{abstract}

One of the classic theories concerning the pathogenesis of inflammatory bowel disease relates to the possible role of luminal antigens in triggering acute attack. ${ }^{1-3}$ Such antigens have been thought to act by inducing an anomalous or exaggerated immunological response causing the release of inflammatory mediators, which, in turn has been thought responsible for the clinical and histological manifestations of the disease.

The possibility that the already damaged mucosa will be traumatised and therefore further damaged by food was the main reason for using 'total bowel rest' in the management of acute attacks of Crohn's disease. ${ }^{4}$ 'Total bowel rest' was, however, achieved at the cost of protein energy malnutrition if standard IV glucose was the sole source of calories given. The use of total parenteral nutrition satisfied the need for 'bowel rest' while permitting the patient to achieve a satisfactory nutritional state. ${ }^{5-8}$ Moreover, the subsequent belief that intraluminal dietary antigens could play a major part in the pathophysiology of inflammation in Crohn's disease was an additional reason for prescribing 'total bowel rest' in patient management. ${ }^{810}$ It has to be emphasised that in most series parenteral nutrition was added to corticosteroid therapy, thus making the case for total parenteral nutrition as primary therapy in Crohn's disease confusing. ${ }^{11}$ There is, however, as far as we are aware no controlled data to support the use of total parenteral nutrition as a unique primary treatment for active Crohn's disease.

In the belief that some food products could exert an adverse effect on the intestine of patients with Crohn's disease, the use of exclusion diets were proposed both as primary treatment and in the prevention of acute attacks of the disease. ${ }^{12}$ Definitive proof, however, concerning the relation between the reintroduction of conventional food ingestion and relapse of the disease has hitherto not been provided.

\section{Use of 'elemental' diets in Crohn's} disease

In the past decade much interest has surrounded the use of predigested chemically defined elemental diets in the management of acute exacerbations of Crohn's disease. In the diets used in the early studies, nitrogen was provided in the form of free L-amino acids. ${ }^{13}$ The rationale for using such diets was based upon the lower antigenicity of free amino acids compared with whole protein. In addition, amino acid, not requiring digestion, was thought to be well absorbed in the upper segments of the small bowel. This was considered to result in some degree of 'bowel rest'. This idea was reinforced by the fact that the elemental diets used contained only small amounts of fat, often in the form of medium chain triglycerides, which required comparatively little luminal lipolysis and micellar solubilisation before absorption.

A number of controlled clinical trials comparing the effects of elemental diet and corticosteroid therapy in the treatment of acute exacerbations of Crohn's disease were performed. ${ }^{14-18}$ In general, results have shown that elemental diets are as effective as corticosteroids in inducing clinical remission in such 
TABLE I Polymeric diets in Crohn's disease

\begin{tabular}{llllll}
\hline Author $($ ref) & Design & Activity index & No & Remission (\%) & Relapse (\%) \\
\hline Greenberg $^{19}$ & PEN $v$ TPN $v$ PPN +oral & CDAI & 51 & $58 v 71 v 60$ & $45 v 58 v 44(12 \mathrm{months})$ \\
Coyle $^{29}$ & PEN & Harvey & 12 & 66 & $66(15 \mathrm{months})$ \\
Bodemari $^{30}$ & PEN & Harvey & 10 & 90 & - \\
Giaffer $^{31}$ & PEN $v$ EEN & CDAI & 30 & $36 v 75$ & - \\
Park $^{32}$ & PEN $v$ EEN & CDAI & 14 & $71 v 29$ & $66 v 100(12 \mathrm{months})$ \\
Raouf $^{33}$ & PEN $v$ EEN & Harvey and Van Hees & 24 & $82 v 78$ & - \\
Rugaud $^{34}$ & PEN $v$ EEN & CDAI & 30 & $73 v 66$ & $77 v 66(12$ months) \\
Author's series $^{40}$ & PEN $v$ prednisone & Van Hees & 32 & $80 v 88$ & $42 v 67$ (12 months) \\
\hline
\end{tabular}

$\mathrm{PEN}=$ polymeric enteral nutrition; EEN = elmental enteral nutrition; $\mathrm{TPN}=$ total parenteral nutrition; $\mathrm{PPN}=$ peripheral parenteral nutrition; CDAI=Crohn's disease activity index.

patients; the time taken to achieve the remission being similar with both treatments. These findings seemed to support the hypothesis that both 'bowel rest' and a decrease in antigenic substances within the intestinal lumen could diminish the inflammatory response in Crohn's disease. Later controlled studies have, however, clearly shown that 'bowel rest' is not a prerequisite in the successful treatment of acute exacerbations of Crohn's disease. ${ }^{19-21}$

On the other hand, results about the relapse rate after remission are controversial. In one trial, there were no differences in the remission rate at three months between diet and corticosteroids. ${ }^{14}$ Two later series showed, however, that the relapse rate after remission induced by elemental diet was higher than that after corticosteroids at nine weeks ${ }^{15}$ and at 12 months. ${ }^{18}$

\section{Use of peptide based 'elemental' diets in Crohn's disease}

Based on results of physiological studies showing better nitrogen absorption from di or tripeptides than from isonitrogenous free amino acid mixtures, ${ }^{22}$ the amino acid source of some elemental diets has been replaced by peptide mixtures of varying chain length and amino acid composition. The osmolality of amino acid based diets is higher than that of peptide based diets. Thus, to achieve the same nitrogen intake, a higher osmotic load would have to be given using amino acid compared with peptide or whole protein containing diets. As diarrhoea in patients with Crohn's disease receiving enteral feeding might be exacerbated by the administration of high osmotic loads, it is perceived by some that the use of the lower osmolar peptide and whole protein based diets could result in the supply of more nitrogen in which case they would be nutritionally more effective than elemental diets. These considerations may be of importance, as patients with acute inflammatory bowel disease are hypermetabolic $^{23}$ and often develop protein energy malnutrition. ${ }^{24}$

With these arguments in mind, a number of controlled clinical trials have compared the efficacy of peptide containing elemental diet and corticosteroid therapy in the management of acute exacerbations of Crohn's disease both in adults ${ }^{25}$ and children. ${ }^{26}$ In the largest controlled clinical trial comparing a peptide based tube fed diet with medical treatment, Lochs et al found that a peptide based diet was less effective than a combination of methylprednisolone and sulphasalazine in the treatment of active Crohn's disease. ${ }^{25}$ In smaller samples of patients, however, peptide based diets have been shown to be as effective in inducing remission in Crohn's disease compared with either corticosteroids or amino acid based diets, with remission rates of higher than $80 \%$ being reported. ${ }^{26-28}$ Note might be made of the finding in Lochs' trial of $44 \%$ of nonresponders to the peptide based diet. This is surprising as it is a figure considerably higher than in other trials.

\section{Use of polymeric enteral diets in Crohn's disease}

The doubts that have been expressed on the efficacy of 'bowel rest' as a prerequisite in the management of acute exacerbations of Crohn's disease, ${ }^{19-21}$ the higher relapse rates in patients with Crohn's disease treated with amino acid containing elemental diets than those in corticosteroids, and the conflicting results of trials with peptide based elemental diets have led other investigators to examine the efficacy of polymeric, whole protein containing enteral diets in the management of acute exacerbation of Crohn's disease.

Several studies have now been published evaluating the effect of polymeric diets in

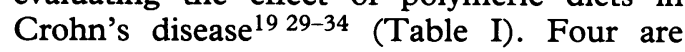
prospective randomised trials assessing the efficacy of polymeric diets compared with 'elemental' diets in inducing remission in Crohn's disease. ${ }^{31-34}$ The analysis of these studies is difficult because of (1) The use of different activity indexes to assess the inflammatory activity; (2) Some studies include no more than 14 cases $^{29} 3032$; (3) The diets studied are not comparable with respect to their nutritional formulation; (4) The relapse rates during the follow up have not always been reported.

It has become traditional to assess inflammatory activity in Crohn's disease by means of clinical and biological parameters and, based on these, various indexes have been reported; the Crohn's disease activity index (CDAI) ${ }^{35}$ and those described by Harvey and Heaton ${ }^{36}$ and Van Hees et al ${ }^{37}$ are most constantly used. Because the number of variables included in the first two indexes are subjective - that is, abdominal pain, degree of well being - their reproducibility is comparatively low. ${ }^{38} 39$ In contrast, all the parameters included in the Van Hees' index can be objectively measured. The comparative importance of the presence of diarrhoea varies from one index to another. This may be of relevance in choosing an index 
TABLE II Composition of the enteral diets (expressed as per cent of the total calories)

\begin{tabular}{|c|c|c|c|c|}
\hline & $\begin{array}{l}\text { Nitrogen } \\
(\%)\end{array}$ & $\begin{array}{l}\text { Carbohydrate } \\
(\%)\end{array}$ & $\begin{array}{l}\text { Fat } \\
(\%)\end{array}$ & Result \\
\hline O'Morain ${ }^{14}$ & \multirow{9}{*}{$\begin{array}{l}\text { AA }(8 \cdot 2) \\
\text { PEP }(18) \\
\text { AA }(8 \cdot 2) \\
\text { POLY }(18) \\
\text { AA }(12) \\
\text { POLY }(13) \\
\text { AA }(8 \cdot 2) \\
\text { AA }(17 \cdot 6) \\
\text { PEP }(18 \cdot 4) \\
\text { POLY }(22)\end{array}$} & \multirow{5}{*}{$\begin{array}{l}90 \\
70 \\
90 \\
48 \\
78 \\
67\end{array}$} & \multirow{5}{*}{$\begin{array}{c}1 \cdot 3 \text { (linoleic } \\
12 \text { (65\% linoleic) } \\
1.3 \text { (linoleic) } \\
36 \text { (80\% linoleic) } \\
15(60 \% \text { MUFA) } \\
19(60 \% \text { MUFA) }\end{array}$} & $\mathrm{AA}=$ steroids \\
\hline Loch $^{25}$ & & & & PEP $<$ steroids \\
\hline Giaffer $^{31}$ & & & & $\mathrm{AA}>\mathrm{POLY}$ \\
\hline Park 32 & & & & \\
\hline Park & & & & POLY $>A A$ \\
\hline Royall $^{28}$ & & 90 & 19 (60\% MUFA) & $A A=P E P$ \\
\hline Ito 41 & & 89 & 0.6 (linoleic) & $\mathrm{AA}>\mathrm{PEP}$ \\
\hline & & 72 & 5 (linoleic) & \\
\hline Authors ${ }^{49}$ & & 46 & $32(50 \%$ MUFA $)$ & POLY $=$ steroids \\
\hline
\end{tabular}

$\mathrm{AA}=$ amino acids; $\mathrm{PEP}=$ peptides $\mathrm{POLY}=$ polymeric $; \mathrm{MUFA}=$ monounsaturated fatty acids.

for trials assessing the effects of enteral nutrition in Crohn's disease in which an increase in diarrhoea may either result as a consequence of worsening of the disease or as a consequence of side effect of the nutritional treatment. In such studies, the use of an index as the CDAI that is loaded towards the daily number of bowel movements would seem not to be the most advisable index to use.

In a number of previous studies, 19293033 the composition of the diets is incompletely reported as only their elemental or polymeric character is stated. In some of the studies it is not clear if the term 'elemental' implies the use of an amino acid or peptide based nitrogen source. ${ }^{34}$ In one trial, ${ }^{31}$ the nutritional formulation of the diets under investigation is not comparable. Thus not only did the test diets have different sources of nitrogen but the lipid content of the polymeric diet was 15 times higher than that of the elemental diet. On the basis of these differences, the conclusion reached by the authors that polymeric diets are not as effective in the treatment of Crohn's disease as elemental diets, may not be justified.

The remaining trials comparing amino acid or peptide based elemental diets with

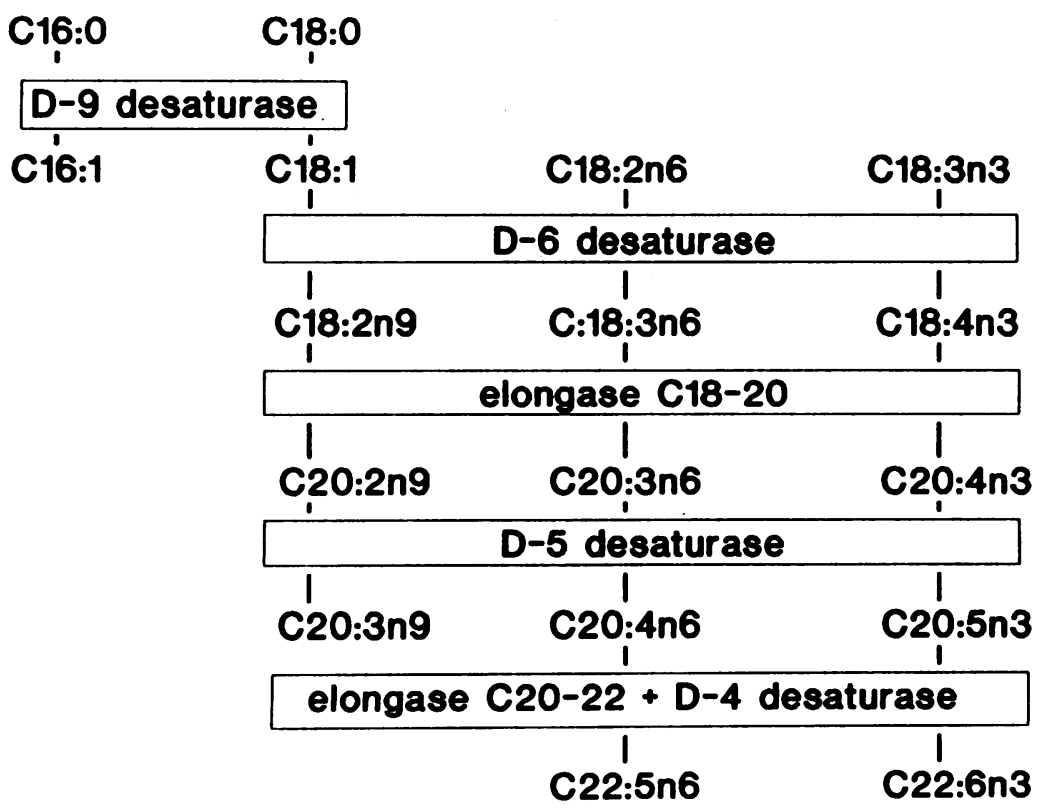

Figure 1: Polyunsaturated fatty acid (PUFA) biosynthesis. $n 6$ and $n 3$ PUFA are synthesised from essential fatty acids (linoleic, C18:2n6; and $\alpha$-linolenic, C18:3n3, respectively) by alternate desaturation and elongation. Dihomo- $\tau$-linolenic (C20:3n6), arachidonic (C20:4n6), and eicosapentaenoic (C20:5n3) acids are the precursors of naturally occurring eicosanoids. In severe essential fatty acid deficiency n9 PUFA may be produced from oleic acid (C18:1). It is noteworthy that each PUFA series produce its derivatives from its own precursors - that is, they are not interconvertible in vivo. polymeric diets have shown a positive primary therapeutic effect of both types of enteral formulation in Crohn's disease. ${ }^{32-34}$ To our knowledge, however, there have been no studies evaluating the effectiveness of polymeric diets in Crohn's disease compared with corticosteroid therapy. We have recently performed such a study. ${ }^{40}$ Thirty two patients with active Crohn's disease were randomised to receive corticosteroids or a polymeric enteral diet. The size of this sample allowed us to detect, with a statistical power of $90 \%$ and an $\alpha$ error of $5 \%$, mean differences in the per cent reduction of the Van Hees' activity index between both groups of $20 \%$. The results showed no differences in the capacity to induce the remission of the disease (diet $80 \%$, corticosteroids $88 \%$ ). The mean difference in the per cent reduction of the Van Hees' activity index between both groups was of $2.5 \%$ ( $95 \%$ confidence intervals $-11 \cdot 8 \%$ to $16 \cdot 8 \%$ ). In addition, relapse rate 12 months after remission was $67 \%$ with corticosteroids and $42 \%$ with the polymeric diet. The results of this trial suggest that polymeric enteral nutrition is safe, well tolerated, cheap, and as effective as corticosteroids in inducing remission in patients with active Crohn's disease. The trend towards a lower relapse rate after the induction of the remission by the diet has to be confirmed in further studies in which a larger number of patients are included.

Influence of the fat composition of enteral diets on the outcome in Crohn's disease

We have been interested in assessing the possible influence that the fat component of enteral diets has on the outcome of patients with Crohn's disease. Table II summarises the composition of some of the enteral diets used as primary therapy in these patients. Some interesting points emerge. The use of diets with a very low fat content $(0 \cdot 6-1 \cdot 3$ per cent of total calories) has been associated with a good outcome. ${ }^{142841}$ The use of those diets containing high quantities of fat (12-30 per cent of total calories) was associated overall with a less favourable outcome. In particular when large amounts of linoleic acid were present, the outcome seemed to be poor. ${ }^{25} 31$ This fatty acid is the precursor of arachidonic acid, which in turn is the substrate for the synthesis of the eicosanoids with the highest proinflammatory activity (leukotriene $B_{4}$, thromboxane $A_{2}$ prostaglandin $E_{2}$ ). The outcome of patients treated with diets containing intermediate or high amounts of fat but containing large proportions of monounsaturated fatty acids was, however, more favourable. ${ }^{3240}$

These findings suggest the possibility that clinical remission achieved with elemental diets might be related to the administration of insufficient substrate for $n-6$ derived eicosanoid synthesis (Fig 1 and 2). In support of this, there are experimental data available showing that low fat diets, ${ }^{42}$ or diets with low essential fatty acid contents ${ }^{43}$ have an immunomodulatory effect in animal studies. Furthermore, essential fatty acid deficiency is 


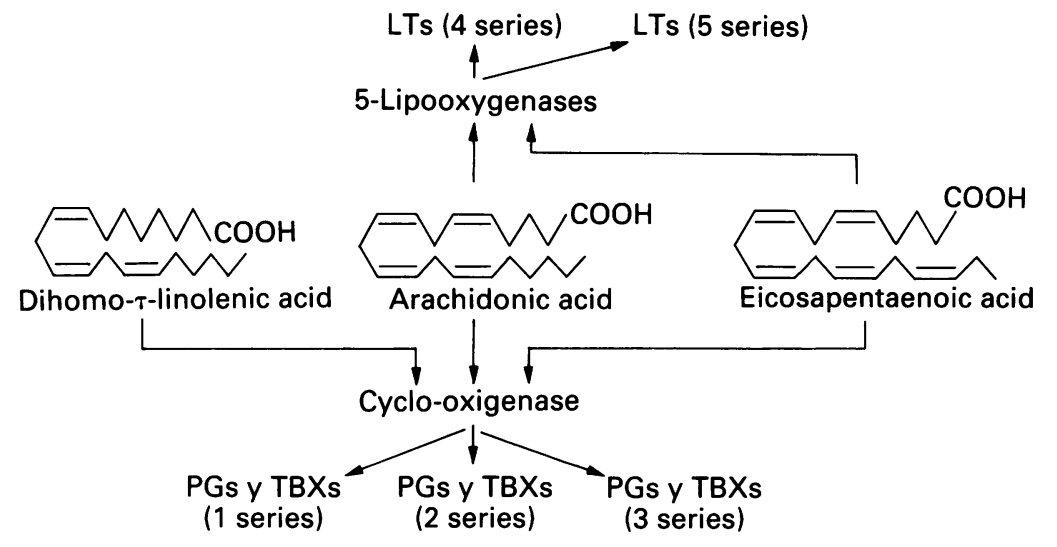

Figure 2: Eicosanoid (prostaglandin (PG), thromboxane (TBX), and leukotriene(LT)) synthesis from long chain $n 6$ and $n 3 P U F A$.

known to diminish acute inflammation ${ }^{44}$ and in other studies to improve experimental colitis induced in the rat. ${ }^{45}$ Recent studies in vitro and in humans emphasise the possible role of fatty acids and their derivatives in mediating inflammation. ${ }^{46-48}$ In this sense, a changed plasma pattern of polyunsaturated fatty acids has been described in inflammatory bowel disease. ${ }^{49}$

In conclusion, there are sufficient data available to suggest that enteral nutrition has a primary therapeutic role in the management of acute exacerbations of Crohn's disease. Further work is needed to explore the possibility that the beneficial effects of enteral nutrition may not be related, as previously supposed, to the composition of the nitrogen source but the composition of the fat component of the enteral formulas so far subjected to clinical trial.

1 Shorter RG, Huizenga KA, Spencer RJ. A working hypothesis for the etiology and pathogenesis of nonspecific inflammatory bowel disease. Dig Dis 1977; 17: specific infl $1024-32$.

2 Ward M. The pathogenesis of Crohn's disease. Lancet 1977; ii: $903-5$.

3 Levi AJ. Diet in the management of Crohn's disease. Gut 1985; 26: 985-8.

4 LeLeiko NS. Nutrition and inflammatory bowel disease. In Kurtz RC, ed. Nutrition and gastrointestinal disease. New York: Churchill Livingstone, 1981: 85-100

5 Fischer JE, Foster GS, Abel RM, Abbot WM, Ryan JA Hyperalimentation as primary therapy for inflammatory bowel disease. Am f Surg 1973; 125: 165-75.

6 Mullen JL, Hargrove WC, Dudrick SJ, Fitts W, Rosato EF Ten years experience with intravenous hyperalimentation and inflammatory bowel disease. Ann Surg 1978; 187: 523-9.

7 Driscoll Jr RH, Rosenberg IH. Total parenteral nutrition in inflammatory bowel disease. Med Clin North Am 1978; 62 185-201.

8 Ostro MJ, Greenberg GR, Jeejeebhoy KN. Total parenteral nutrition and complete bowel rest in the management of Crohn's disease. IPEN 1985; 9: 280-7.

9 Rhodes J, Rose J. Does food affect acute inflammatory bowel disease? The role of parenteral nutrition, elemental and exclusion diets. Gut 1986; 27: 471-4.

10 Matuchansky C. Parenteral nutrition in inflammatory bowel disease. Gut 1986; 27 (suppl): 81-4,

11 Payne-James JJ, Silk DBA. Total parenteral nutrition as primary treatment in Crohn's disease - RIP? Gut 1988 29: 1304-8.

12 Alun Jones $\mathrm{V}$, Dickinson RJ, Workman $\mathrm{E}$, Wilson AJ, Freeman AH, Hunter JU. Crohn's disease: maintenance Freeman AH, Hunter JU. Crohn's disease:
of remission by diet. Lancet 1985 ; ii: 177-80.

13 O'Morain C, Segal AW, Levi AJ. Elemental diets in the treatment of acute Crohn's disease. BMF 1980; 281: 1173-5.

14 O'Morain C, Segal AW, Levi AJ. Elemental diet as primary treatment of acute Crohn's disease. BMf 1984; 288 : 1859-62.

15 Seidman EG, Boutillier L, Weber AM, Roy CC, Morin CL. Elemental diet versus prednisone as primary treatment of Crohn's disease. Gastroenterology 1986; 90: A1625.

16 Saverymuttu S, Hodgson HJF, Chadwick VS. Controlled trial comparing prednisolone with elemental diet plus non-absorbable antibiotics in active Crohn's disease. Gut 1985; 26: 994-8.

17 Hunt JB, Payne-James JJ, Palmer KR, Kumar PK, Clark MR, Farthing MJG, et al. A randomized controlled diet of elemental diet of elemental diet and prednisolone as primary therapy in acute exacerbations of Crohn' disease. Gastroenterology 1989; 96: A224

18 Gorard DA, Hunt JB, Payne-James J, Palmer KR, Kumar PJ, Clark ML, et al. Early response and subsequen relapse rates in Crohn's disease treated with elementa diet or prednisolone. A controlled trial. Gastroenterology 1991; 100: A213.

19 Greenberg GR, Fleming CR, Jeejeebhoy KN, Rosenberger IH, Sales D, Tremaine WJ. Controlled trial bowel rest and nutritional support in the management of Crohn's disease. Gut 1988; 29: 1309-15.

20 Lochs H, Meryn S, Marosi L, Ferenci P, Hortag H. Has total bowel rest a beneficial effect in the treatment of Crohn's disease? Clin Nutr 1983; 2: 61-4.

21 Alun Jones V. Comparison of total parenteral nutrition and elemental diet in induction of remission of Crohn's disease. Long-term maintenance of remissions by personalized
exclusion diets. Dig Dis Sci 1987; 32 (suppl): 100-7S.

22 Keohane PP, Silk DBA. Peptides and free aminoacids. In Rombeau JL, Caldwell MD, eds. Enteral and tube feeding. 1st ed. Philadelphia; WB Saunders, 1984: 44-59.

23 Barot LB, Rombeau JL, Steinberg JJ, Crosby LO, Feure ID, Mullen JL. Energy expenditure in patients with inflammatory bowel disease. Arch Surg 1981; 116: 460-2.

24 Gassull MA, Abad A, Cabré E, González-Huix F, Giné JJ, Dolz C. Enteral nutrition in inflammatory bowel disease. Gut 1986; 27: 76-80.

25 Lochs H, Steinhardt HJ, Klaus-Wentz B, Zeitz M Vogelsang $\mathrm{H}$, Sommer $\mathrm{H}$, et al. Comparison of enteral
nutrition and drug treatment in active Crohn's disease. Results of the European Cooperative Crohn's disease Results of the European Cooperative Cro
study IV. Gastroenterology 1991; 101: 881-8.

26 Sanderson IR, Udeen S, Davies PSW, Savage MO, WalkerSmith JA. Remission induced by an elemental diet in small bowel Crohn's disease. Arch Dis Child 1987; 61: 123-7.

27 Middleton SJ, Riordan AM, Hunter JO. Comparison of elemental and peptide-based diets in the treatment of acute Crohn's disease. Ital f Gastroenterol 1991; 23: 609.

28 Royall D, Kahan I, Baker JP, Allard JP, Habal FM, Jeejeebhoy KN. Clinical and nutritional outcome of an elemental versus semi-elemental diet in active Crohn's disease. Gastroenterology 1992; 102: A576.

29 Coyle BL, Sladen GE. Whole protein diet in the treatment of acute uncomplicated Crohn's disease. $₹ \mathrm{Hum}$ Nutr of acute uncomplicated

30 Bodemar G, Nilsson L, Smedh K, Larsonn J. Nasogastric feeding with polymeric, whole protein low fat diet in Crohn's disease. $¥$ Clin Nutr Gastroenterol 1991; 6: 75-83.

31 Giaffer MH, North G, Holdsworth CD. Controlled trial of polymeric versus elemental diet in treatment of active Crohn's disease. Lancet 1990; 335: 816-9.

32 Park RHR, Galloway A, Danesh BJZ, Russell RI. Doubleblind controlled trial of elemental diet and polymeric diets as primary treatment in active Crohn's disease. Eur $\mathcal{F}$ as primary treatment in active Croh
Gastroenterol Hepatol 1991; 3: 483-90.

33 Raouf AH, Hildrey V, Daniel J, Walker RJ, Krasner N, Elias $\mathrm{E}$, et al. Enteral feeding as sole treatment for Crohn's E, et al. Enteral feeding as sole treatment for Crohn's disease: controlled trial of whole protein $\mathrm{v}$ aminoacid
based feed and a case study of dietary challenge. Gut based feed and a
$1991 ; 32: 702-7$.

34 Rigaud D, Cosnes J, Le Quintrec Y, René E, Gendre JP, Mignon $M$. Controlled trial comparing two types of enteral nutrition in the treatment of active Crohn's disease: elemental v polymeric trial. Gut 1991; 32: 1492-7.

35 Best WR, Becktel JM, Singleton JW, Kern F. Development of a Crohn's disease activity index. National Cooperative Crohn's disease study. Gastroenterology 1976; 70: 439-44.

36 Harvey RF, Heaton KW. Dietary treatment of Crohn's disease. Lancet 1985; ii: 453-4.

37 Van Hees PAM, Van Elteren RH, Van Lier HJJ, Van Tongeren JHM. An index of inflammatory activity in patients with Crohn's disease. Gut 1980; 21: 279-86.

38 DeDombal FT, Softley A. IOIBD report no 1: observer variation in calculating indices of severity and activity in Crohn's disease. Gut 1987; 28: 474-81.

39 Crama-Bohbouth G, Peña AS, Biedmond I, Verspaget HW, Blok D, Arndt JW, et al. Are activity indices helpful in assessing active intestinal inflammation in Crohn's disease? Gut 1989; 30: 1236-40.

40 González-Huiz F, de Leon R, Fernández-Bañares F, Esteve $\mathrm{M}$, Cabré E, Acero D, et al. Polymeric enteral diets as primary treatment of active Crohn's disease. A prospecprimary treatment of active Crohn's disease. A pro

41 Ito $K$, Hiwatashi N, Kinouchi Y, Yamazaki $H$, Toyota $T$. Improvement of abnormal intestinal permeability in active Improvement of abnormal intestinal permeability in active Crohn's disease

42 Morrow WJW, Homsy J, Swanson CA, Ohashi Y, Estes J, Levy JA. Dietary fat influences the expression of auto immune disease in MLR $1 \mathrm{pr} / 1 \mathrm{pr}$ mice. Immunology 1986 59: 439-43.

43 Schreiner GF, Flye W, Brunt E, Korber K, Lefkowith JB Essential fatty acid deplection of renal allografts and prevention of rejection. Science 1988; 240: 1032-3.

44 Denko CW. Modification of adjuvant inflammation in rats deficient irf essential fatty acids. Agents Actions 1976; 65: 636-41. 
45 Lohoues MJ, Russo P, Gurbindo C, Roy C, Levy E, Lepage $\mathrm{G}$, et al. Essential fatty acid deficiency improves the course of experimental colitis in the rat: possible role of dietary immunomodulation. Gastroenterology 1992; 102: A655.

46 Strasser T, Fischer S, Weber PC. Leukotriene B5 is formed in human neutrophils after dietary supplementation with eicosapentaenoic acid. Proc Natl Acad Sci USA 1985; 82: 1540-3.

47 Lee TH, Hoover RL, Williams JD, Sperling RI, Ravalese J, Spur BW, et al. Effect of dietary enrichment with eicosapentaenoic and docosahexaenoic acids on in vitro neutrophil and monocyte leukotriene generation and neutrophil function. $N$ Engl $\mathcal{F}$ Med 1985; 312: 1217-24. 48 Endres S, Ghorbani R, Kelley VE, Georgilis K, Lonnemann G, van der Meer JWM, et al. The effect of dietary supplementation with $n-3$ polyunsaturated fatty acids on the synthesis of interleukin-1 and tumor necrosis factor by mononuclear cells. N Engl f Med 1989; 320: 265-71.

49 Esteve M, Ramírez M, Fernández-Bañares F, Abad-Lacruz A, Gil A, Cabré E, et al. Plasma polyunsaturated fatty acid pattern in active inflammatory bowel disease. Gut 1992; 33: 1365-9. 